RAD Conference Proceedings, vol. 2, pp. 115-120, 2017

www.rad-proceedings.org

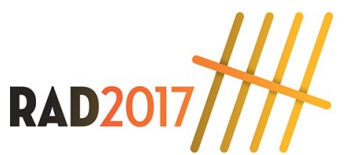

\title{
THE ECOTOXICOLOGICAL IMPACT OF THE NUCLEAR FACILITIES’ EFFLUENT AND CS-137 ON THE TEST ORGANISM LEPIDIUM SATIVUM
}

\author{
O. Jefanova ${ }^{1^{*}}$, E.D. Marčiulioniené ${ }^{1}$, D. Montvydiené ${ }^{1}$, \\ Z. Žukauskaité2 ${ }^{2}$ B. Lukšiené ${ }^{2}$, J. Mažeika1 \\ ${ }^{1}$ State Research Institute Nature Research Centre, Vilnius, Lithuania \\ ${ }^{2}$ State Research Institute Center for Physical Sciences and Technology, Vilnius, Lithuania
}

\begin{abstract}
The aim of this study is to assess the impact of nuclear facility effluent during decommissioning process on the seed germination and growth of the test organism Lepidium sativum, as well as to assess the biological effect of Cs-137 on the roots (meristematic cells) and sprouts (cells of parenchyma) of the test organism Lepidium sativum. The investigations were performed on water and the bottom sediment from the monitoring station of Lake Drūkšiai (the cooling-pond of the Ignalina NPP), as well as from the Ignalina NPP's effluent channels IRD-1,2 (industrial rain drainage channel) and TWO (technical water outlet channel) before the INPP shutdown (2007-2009) and after (2010-2015). The ${ }^{137}$ Cs impact on the test organism using the low activity concentration solutions of 25 and $250 \mathrm{~Bq} / \mathrm{L}$ was also investigated.
\end{abstract}

Key words: Cs-137, ecotoxicological effect, effluent channels, Lepidium sativum, the Ignalina NPP

DOI: $10.21175 /$ RadProc.2017.24

\section{INTRODUCTION}

Significant quantities of artificial radionuclides have already entered, and may enter in the future, in the environment. It may happen during operation of NPPs, after their shutdown and during decommissioning process in conjunction with dismantling works, after nuclear accidents (Chernobyl NPP, Fukishima NPP, etc.), and during the implementation of nuclear power development projects. The dispersion of the artificial radionuclides and their distribution in the biotic and abiotic ecosystem components are associated with the ongoing decommissioning of the Ignalina NPP in Lithuania. For the reasons mentioned above, the investigation of the biological effects caused by the artificial radionuclides is always relevant.

It is very important to assess the effects caused by the artificial radionuclides on biota. However, the consequences of the ionizing radiation impact on biota have not been sufficiently investigated yet. So far, the ionising radiation doses are rated only for humans. Therefore, it is necessary to find the assessment ratio of radiation safety criteria for humans and biota. This requires scientific data on ionizing radiation impact on biota at both the organism and cellular level. However, due to the high biodiversity and different environmental conditions the data about biological effects derived by ionising radiation are still limited.
NPPs are the important objects requiring regular and sufficient radioecological assessment. The maximum quantity of some radionuclides intake from the NPP into the cooling pond is a known fact $[1,2]$. A variety of the physical, chemical and biological (physiological, genetic, etc.) methods is used for the assessment of radionuclide toxicity. Various biological tests with the so-called test organisms, widely used for the investigations of the toxicity of external factors, can be applied to the studies of the biological effects impacted by radionuclides [3-9].

The aim of this study is to assess the impact of nuclear facility effluent during decommissioning process on seed germination and growth of the test organism Lepidium sativum, as well as to assess the biological effect of $\mathrm{Cs}-137$ on the roots (meristematic cells) and sprouts (cells of parenchyma) of the test organism Lepidium sativum.

\section{OBJECT AND METHODS}

In order to assess the radioecological condition of Lake Drūkšiai, the samples of the dominant macrophyte species (Ceratophyllum demersum, Myriophyllum spicatum, Potamogeton sp.) were collected with a special hook in the monitoring stations 1, 4, 6 and 7 of Lake Drūkšiai, as well as in the Ignalina NPP effluent channels (the Industrial Rain Drainage channel (IRD-1,2) and the Technical Water Outlet channel (TWO)) in July-August 2007-2015 (Fig. 1). In

*olga.jefanova@gamtostyrimai.lt 
the same time the samples of the bottom sediment were collected using the Ekman bottom grab sampler (the area of sampler $20 \times 20 \mathrm{~cm}$ ).

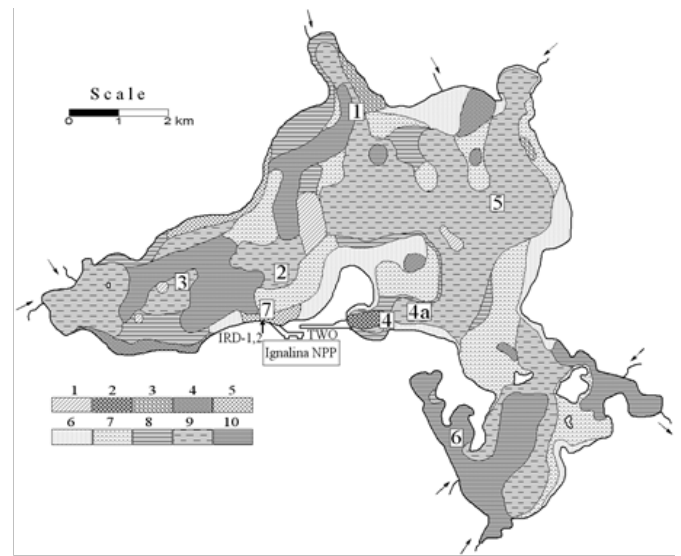

Figure 1. Lake Drūkšiai monitoring stations (used in this work are 1,4,6,7, IRD-1,2 and TWO) and bottom sediment types

[10-12]: 1- till (morainic clay, loam and sandy loam), 2 carbonate sediments, 3 - gravel, 4 - coarse-grained sand, 5 various-grained sand, 6 - fine-grained sand, 7 - silty sand, 8

- coarse silt mud, 9 - fine silt mud, 10 - silt-pelitic mud.

The samples were dried in the laboratory at 20$22{ }^{\circ} \mathrm{C}$. Macrophytes samples were incinerated in a muffle furnace $\left(430^{\circ} \mathrm{C}\right)$. The bottom sediment samples were homogenized using a ceramic pestle and were passed through sieves with holes of $0.8 \mathrm{~mm}$ in a diameter $[1,2]$.

The measurements of the radionuclides in the samples were accomplished on the gamma-ray spectrometers with $\mathrm{Ge}(\mathrm{Li})$ and HPGe detectors at the Centre for Physical Sciences and Technology, Vilnius, and at the Nature Research Centre, Vilnius, as described in [13].

The Lepidium sativum toxicity method was used as modified in [14] methodology. The $9 \mathrm{~mL}$ water solution (investigated water from monitoring points or used Cs-137 aquatic solutions and distilled water as control) plus 2 pieces of filter paper in case of the bottom sediment, a 5 $-6 \mathrm{~mm}$ layer of the bottom sediment plus 1 piece of filter paper. On this base, 25 seeds of Lepidium sativum (density $1 \times 1 \mathrm{~cm}$ ) were put in 5 repeats. The Petri plates were kept in darkness for 48 hours at a constant $24 \pm 1{ }^{\circ} \mathrm{C}$ temperature. The sample toxicity was assessed according to the seed germination and roots growth. The toxicity level was assessed according to the modified [15] scale. In cases with Cs-137 solutions (25 and $250 \mathrm{~Bq} / \mathrm{L}$ activity concentration) after the experiment performance, Lepidium sativum plants were washed and divided with the scissors into stems and roots. In these parts, the accumulated Cs-137 activity concentration was measured.

For statistical calculations programme STATISTICA six sigma, (C) StatSoft (2007) was used.

\section{RESULTS AND DISCUSSION}

The Cs-137 activity concentrations in macrophytes of Lake Drūkšiai monitoring stations 1, 4, 6 and 7 have little changed (from 5 to $13 \mathrm{~Bq} / \mathrm{kg} \mathrm{d}$. w.) (Table 1) before the shutdown of the Ignalina NPP (period 2007-2009). After the Ignalina NPP shutdown (20102015), Cs-137 activity concentrations in macrophytes of Lake Drūkšiai monitoring stations 1, 4 and 7 were similar to those before the shutdown. Only at the monitoring station 6, the macrophyte Cs-137 activity concentration was <mda after the Ignalina NPP shutdown.

In the Ignalina NPP's effluent IRD-1,2 channel, Cs-137 activity concentration in macrophytes in 2008 was much higher than in 2007 or 2009 (Table 1). In 2008, even Cs-134 was easy detectable in IRD-1,2 channel macrophytes with level of $183 \mathrm{~Bq} / \mathrm{kg} \mathrm{d}$. w. Meantime Cs-137 activity concentration in IRD-1,2 channel's bottom sediment was much less than in macrophytes. During the investigated period (20072015), Cs-137 activity concentration in IRD-1,2 macrophytes differed slightly (Table 1). However, in the bottom sediment Cs-137 activity concentration was higher after the Ignalina NPP shutdown (from 14 to 27 $\mathrm{Bq} / \mathrm{kg}$ d. w.) than before the Ignalina NPP shut down (from $<0,3$ to $11 \mathrm{~Bq} / \mathrm{kg}$ d. w.).

It was found that water of all monitoring stations and effluent channels of the Ignalina NPP had no impact on the seed germination of the test organism before (2007-2009) and after (2010-2015) the Ignalina NPP shutdown. However, during the 20072009 period, water of the effluent channels was found to have the impact upon the root growth of this test organism. After the Ignalina NPP shutdown, only in 2010 the water of the effluent channels (IRD-1,2, TWO) was found to be moderately toxic to the root growth of Lepidium sativum. In all other cases, after the Ignalina NPP shutdown, the water was slightly toxic to Lepidium sativum root growth.

In 2008, 2009 and 2010, only the bottom sediments from the channels IRD-1,2 and at the monitoring station 7 showed a strong and moderate toxicity to Lepidium sativum seed germination. In all other cases, the bottom sediment was not toxic to Lepidium sativum seed germination. Very strong toxicity of the bottom sediments to the root growth of the test organism was recorded only in IRD-1,2 channels and at monitoring station 7 (the IRD-1,2 impact zone) in 2008, 2009 and 2010 (Table 2). In all other cases, the bottom sediments had moderate and weak toxicity impact on the root growth of the test organism Lepidium sativum. The data suggest that the bottom sediments are more toxic to the test organism Lepidium sativum than water.

The data show that in 2008, 2009 and 2010 the bottom sediments from IRD-1,2 and at the monitoring station 7 had a strong toxicity impact on Lepidium sativum. As already mentioned, during the same period relatively higher activity concentrations of the artificial radionuclides were determined in macrophytes from IRD-1,2 and 7 monitoring stations.

It was found that over the study period the toxic effect of water at Lake Drūkšiai monitoring stations on the test organism Lepidium sativum decreased from the moderate (before the shutdown of the Ignalina NPP) to weak (after the shutdown). However, the toxicity of the bottom sediments to the test organism Lepidium sativum remained essentially the same throughout the whole study period. 
Table 1. Cs-137 activity concentrations (Bq/kg d. w.) in macrophytes and bottom sediment in Lake Drūkšiai monitoring stations and the Ignalina NPP effluent channels

\begin{tabular}{|c|c|c|c|c|c|c|c|c|c|c|c|c|}
\hline \multirow[t]{3}{*}{ Year } & \multicolumn{8}{|c|}{ Lake Drūkšiai monitoring stations } & \multicolumn{4}{|c|}{ Ignalina NPP effluent channels } \\
\hline & \multicolumn{2}{|c|}{1} & \multicolumn{2}{|r|}{4} & \multicolumn{2}{|c|}{6} & \multicolumn{2}{|c|}{7} & \multicolumn{2}{|c|}{ TWO } & \multicolumn{2}{|c|}{ IRD-1,2 } \\
\hline & $\begin{array}{l}\text { macro } \\
\text { phytes }\end{array}$ & $\begin{array}{l}\text { bottom } \\
\text { sediment }\end{array}$ & $\begin{array}{l}\text { macro } \\
\text { phytes }\end{array}$ & $\begin{array}{c}\text { bottom } \\
\text { sediment }\end{array}$ & $\begin{array}{l}\text { macro } \\
\text { phytes }\end{array}$ & $\begin{array}{l}\text { bottom } \\
\text { sediment }\end{array}$ & $\begin{array}{l}\text { macro } \\
\text { phytes }\end{array}$ & $\begin{array}{l}\text { bottom } \\
\text { sediment }\end{array}$ & $\begin{array}{l}\text { macro } \\
\text { phytes }\end{array}$ & $\begin{array}{l}\text { bottom } \\
\text { sediment }\end{array}$ & $\begin{array}{l}\text { macro } \\
\text { phytes }\end{array}$ & $\begin{array}{l}\text { bottom } \\
\text { sediment }\end{array}$ \\
\hline & \multicolumn{12}{|c|}{ Before the Ignalina NPP shutdown } \\
\hline 2007 & $13 \pm 1$ & $184 \pm 3$ & $7 \pm 1$ & $145 \pm 9$ & $6 \pm 1$ & $64 \pm 2$ & $11 \pm 1$ & $6.0 \pm 0.4$ & $4 \pm 1$ & $1.0 \pm 0.1$ & $20 \pm 2$ & $<0,3$ \\
\hline 2008 & $5 \pm 2$ & $133 \pm 7$ & - & $76 \pm 4$ & - & - & $11 \pm 3$ & $19 \pm 2$ & $8 \pm 2$ & $1.0 \pm 0.1$ & $309 \pm 39$ & $\mathbf{1 1} \pm 2$ \\
\hline \multirow[t]{2}{*}{2009} & $6 \pm 1$ & $128 \pm 8$ & $7 \pm 1$ & $78 \pm 4$ & $10 \pm 1$ & $184 \pm 9$ & - & $31 \pm 3$ & $4 \pm 1$ & $2.0 \pm 0.2$ & $18 \pm 1$ & $1.1 \pm 0.4$ \\
\hline & \multicolumn{12}{|c|}{ After the Ignalina NPP shutdown } \\
\hline 2010 & $8 \pm 2$ & - & $15 \pm 4$ & $37 \pm 4$ & - & - & - & $42 \pm 2$ & $10 \pm 4$ & - & $19 \pm 3$ & $14 \pm 2$ \\
\hline 2011 & $9 \pm 3$ & $115 \pm 5$ & $4 \pm 1$ & $28 \pm 2$ & $<$ mda & $151 \pm 14$ & $8 \pm 4$ & $12 \pm 2$ & $4 \pm 2$ & - & $23 \pm 5$ & - \\
\hline 2012 & $13 \pm 4$ & $111 \pm 7$ & $<$ mda & $46 \pm 6$ & - & $107 \pm 10$ & - & $15 \pm 3$ & $<$ mda & - & $37 \pm 8$ & $19 \pm 3$ \\
\hline 2015 & $15^{ \pm 4}$ & $124 \pm 7$ & - & - & $<$ mda & $93 \pm 6$ & - & - & $13 \pm 5$ & - & $25 \pm 4$ & $27 \pm 3$ \\
\hline
\end{tabular}

Table 2. Toxicity impact of bottom sediments from Lake Drūkšiai monitoring stations and the Ignalina NPP effluent channels on root growth of the test organism Lepidium sativum

\begin{tabular}{|c|c|c|c|c|c|c|c|c|c|c|c|c|c|c|}
\hline \multirow{3}{*}{$\begin{array}{l}\text { Monito- } \\
\text { ring } \\
\text { stations } \\
\text { and } \\
\text { effluent } \\
\text { channels }\end{array}$} & \multicolumn{6}{|c|}{ Before the Ignalina NPP shutdown } & \multicolumn{8}{|c|}{ After the Ignalina NPP shutdown } \\
\hline & \multicolumn{2}{|c|}{2007} & \multicolumn{2}{|c|}{$\underline{2008}$} & \multicolumn{2}{|c|}{$\underline{2009}$} & \multicolumn{2}{|c|}{$\underline{\underline{2010}}$} & \multicolumn{2}{|c|}{2011} & \multicolumn{2}{|c|}{2012} & \multicolumn{2}{|c|}{2015} \\
\hline & $\begin{array}{c}\text { Root } \\
\text { growth, } \\
\%\end{array}$ & $\begin{array}{l}\text { Toxi- } \\
\text { city }\end{array}$ & \begin{tabular}{|c|} 
Root \\
growth, \\
$\%$
\end{tabular} & $\begin{array}{l}\text { Toxi- } \\
\text { city }\end{array}$ & $\begin{array}{c}\text { Root } \\
\text { growth, } \\
\%\end{array}$ & $\begin{array}{l}\text { Toxi- } \\
\text { city }\end{array}$ & $\begin{array}{c}\text { Root } \\
\text { growth, } \\
\%\end{array}$ & $\begin{array}{l}\text { Toxi- } \\
\text { city }\end{array}$ & $\begin{array}{c}\text { Root } \\
\text { growth, } \\
\%\end{array}$ & $\begin{array}{l}\text { Toxi- } \\
\text { city }\end{array}$ & $\begin{array}{c}\text { Root } \\
\text { growth, } \\
\%\end{array}$ & $\begin{array}{l}\text { Toxi- } \\
\text { city }\end{array}$ & $\begin{array}{c}\text { Root } \\
\text { growth, } \\
\%\end{array}$ & $\begin{array}{l}\text { Toxi- } \\
\text { city }\end{array}$ \\
\hline & \multicolumn{14}{|c|}{ Lake Drūkšiai } \\
\hline 1 & $76 \pm 3$ & $\begin{array}{c}\text { interme } \\
\text { diate }\end{array}$ & $\begin{array}{c}85^{ \pm} \\
3\end{array}$ & weak & $86 \pm 2$ & weak & - & - & $55 \pm 2$ & potent & $71 \pm 2$ & $\begin{array}{c}\text { interme } \\
\text { diate }\end{array}$ & $105 \pm 8$ & $\begin{array}{c}\text { Stimu- } \\
\text { lant }\end{array}$ \\
\hline 4 & $61 \pm 4$ & $\begin{array}{c}\text { interme } \\
\text { diate }\end{array}$ & $\begin{array}{c}78 \pm \\
3\end{array}$ & $\begin{array}{c}\text { interme } \\
\text { diate }\end{array}$ & $77 \pm 1$ & $\begin{array}{c}\text { interme } \\
\text { diate }\end{array}$ & $67 \pm 1$ & $\begin{array}{c}\text { interme } \\
\text { diate }\end{array}$ & $82 \pm 2$ & weak & $88 \pm 8$ & weak & - & - \\
\hline 6 & $68 \pm 3$ & $\begin{array}{c}\text { interme } \\
\text { diate }\end{array}$ & - & - & $80 \pm 3$ & $\begin{array}{c}\text { interme } \\
\text { diate }\end{array}$ & - & - & $70 \pm 2$ & $\begin{array}{l}\text { interme } \\
\text {-diate }\end{array}$ & $75 \pm 1$ & $\begin{array}{c}\text { interme } \\
\text { diate }\end{array}$ & $96 \pm 3$ & not \\
\hline \multirow[t]{2}{*}{ Z } & $71 \pm 4$ & $\begin{array}{c}\text { interme } \\
\text { diate }\end{array}$ & o & $\begin{array}{l}\text { very } \\
\text { toxic }\end{array}$ & $15 \pm 1$ & $\begin{array}{l}\text { very } \\
\text { toxic }\end{array}$ & o & $\begin{array}{l}\text { very } \\
\text { toxic }\end{array}$ & $68 \pm 3$ & $\begin{array}{c}\text { interme } \\
\text {-diate }\end{array}$ & $82 \pm 2$ & weak & - & - \\
\hline & \multicolumn{14}{|c|}{ The Ignalina NPP effluent channels } \\
\hline TWO & $52 \pm 6$ & potent & $\begin{array}{c}64 \pm \\
2\end{array}$ & $\begin{array}{c}\text { interme } \\
\text { diate }\end{array}$ & - & - & - & - & - & - & - & - & - & - \\
\hline$\frac{\text { IRD- }}{\underline{1,2}}$ & $80 \pm 5$ & $\begin{array}{c}\text { interme } \\
\text { diate }\end{array}$ & $\begin{array}{c}38 \pm \\
2\end{array}$ & toxic & - & - & $\mathrm{O}$ & $\begin{array}{l}\text { very } \\
\text { toxic }\end{array}$ & - & - & $65 \pm 3$ & $\begin{array}{c}\text { interme } \\
\text { diate }\end{array}$ & $82 \pm 4$ & weak \\
\hline
\end{tabular}

Macrophytes are perennial organisms, however their biomass (stems and leaves) grows and accumulates admixtures only during vegetation period (from spring to $\sim$ September). After vegetation period the disintegrating biomass drops to the bottom and forms fraction of bottom sediment composition. It is known, Cs-137 is a hydrophobic element. Entered into aquatic ecosystem it rapidly distributes between bottom sediment and ecosystem biotic components (plants, fishes, insect larvae's, phyto- and zooplankton, etc.) [16]. In their live cycle the macrophytes compete with water and are a barrier retaining Cs-137 (in this case) along water flow in IRD-1,2 channel [17]. In all investigated stations, it is significant differences between Cs-137 activity concentration and toxicity impact of water on Lepidium sativum root growth $(\mathrm{p}=0.038)$.

As discussed above, the increase of Cs-137 activity concentration in IRD-1,2 macrophytes in 2008 evidenced the higher annual discharge rate of this radionuclide. Despite the Cs-137 activity concentration in IRD-1,2 channel bottom sediment was very low (only about $11 \mathrm{~Bq} / \mathrm{kg}$ d.w., see Table 1), a strong toxic response of Lepidium sativum roots to this material was detected in 2008 and two years later (Table 2).

According to macrophytes live cycle for all studied stations was found significant moderately correlation 
（R=0.608231, $\quad \mathrm{p}<0.05 ）$ between $\mathrm{Cs}-137$ activity concentrations in macrophytes and bottom sediment and the toxicity of bottom sediment to Lepidium sativum root growth in next year (the toxicity effect delay - one year). For the IRD-1,2 channel and 7 monitoring station of Lake Drūkšiai it was not found correlation of Cs-137 activity concentration in macrophytes and water or bottom sediment toxicity with delay of one or two years. The correlation coefficients between Cs-137 activity concentration in bottom sediment and toxicity of bottom sediment on Lepidium sativum roots grows were following: $\mathrm{R}=0.48$ with delay of one year, $\mathrm{R}=0.54$ with delay of two years. Compared to previous case the correlation coefficients between Cs-137 activity concentration in bottom sediment and toxicity of water on Lepidium sativum roots grows were higher: $\mathrm{R}=0.79$ with delay one year, $\mathrm{R}=0.89$ with delay of two years.

It is known, that concentration of stable Cs-133 about $200 \mu \mathrm{M}$ can be toxic to plants [18]. The data presented in [19] shows that the concentration of Cs137 of $0.2 \mathrm{nM}$ can have an impact on the electrophysiological parameters of algae Nitellopsis obtuse. On other hand, the experiments showed that Cs-137 activity concentration of $400 \mathrm{~Bq} / \mathrm{L}$ and higher causes a weak stimulated response to Lepidium sativum stems and roots $[19,20]$. In this study, we carried out the experiment with the lower Cs-137 concentration. This was supported by two findings. Firstly, the toxicological response of Lepidium sativum to bottom sediment from Lake Drūkšiai was strongly negative during period of 2008-2010. Secondly, Cs-137 activity concentration in the IRD-1,2 channel was $11 \pm 2$ $\mathrm{Bq} / \mathrm{kg}$ d.w. in bottom sediment and $309 \pm 39 \mathrm{~Bq} / \mathrm{kg}$ d.w. in macrophytes in 2008 (Table 1).

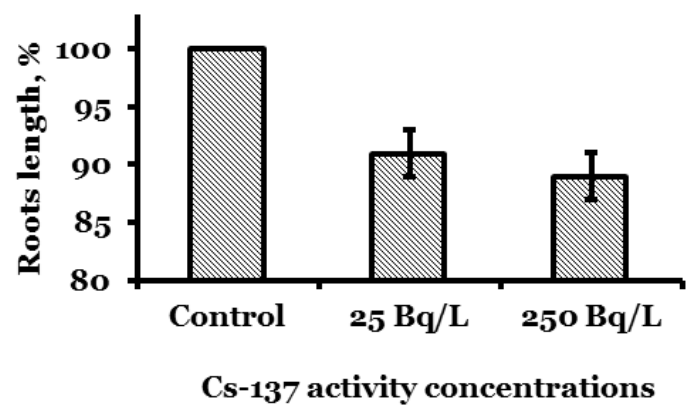

Figure 2. The effect of Cs-137 (activity concentrations 25 and $250 \mathrm{~Bq} / \mathrm{L}$ ) on the Lepidium sativum root length

Figures 2 and 3 show the effect of Cs-137 on the morphological parameters of Lepidium sativum- root length and biomass of roots and stems. In case of Cs-137, the activity concentration increased 10-fold (from 25 to $250 \mathrm{~Bq} / \mathrm{L}$ ), the root length decreased by 9 and $11 \%$ respectively, as compared to the control. Increasing the Cs-137 activity concentration, stem and root biomass decreased very slightly. In both cases the impact of the increased Cs-137 activity concentration was weak toxicity compare to control and cannot give the reaction observed in natural condition 2008-2010 period in IRD-1,2 channel.
Despite the increased Cs-137 accumulation in roots of the test organism Lepidium sativum, at $250 \mathrm{~Bq} / \mathrm{L}$ activity concentrations, the toxic effects on the root lengths were equal in both cases of 25 and $250 \mathrm{~Bq} / \mathrm{L}$ activity concentrations. It can be inferred that Lepidium sativum is not very sensitive to the Cs-137 impact.

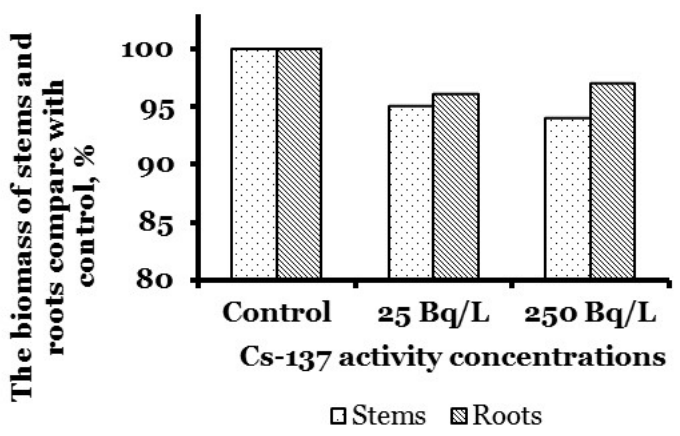

Figure 3. The effect of Cs-137 (activity concentrations 25 and $250 \mathrm{~Bq} / \mathrm{L}$ ) on biomass of roots and stems of test organism Lepidium sativum

\section{CONCLUSIONS}

After the shutdown of the Ignalina NPP Unit One, the activity concentrations of Cs-137 in the bottom sediments and macrophytes of Lake Drūkšiai decreased, changing slightly in the subsequent decommissioning period. The highest Cs-137 activity concentrations in macrophytes were found in the effluent channels IRD-1,2 earlier (especially in 2008).

The assessment of water and the bottom sediment toxicity to the test organism (plant) Lepidium sativum in Lake Drūkšiai and effluent channels of the Ignalina NPP shows that the ecotoxicological condition of the lake has changed a little (2007-2015). The exception is IRD-1,2 effluent channel and 7 monitoring stations (impact zone of IRD-1,2) where toxic response existed in 2008-2010.

However, it exists statistically significant moderate correlation between in $\mathrm{Cs}-137$ in macrophytes and bottom sediment and toxicity of bottom sediment to Lepidium sativum roots growth with one year delay. Investigated Cs-137 activity concentrations were not toxic to the plant test organism Lepidium sativum, i.e. they had no toxic impact on the growth of both roots and stems.

It can be assumed that the elevated toxicity of water and the bottom sediments in IRD-1,2 and 7 at monitoring stations could have been induced not only by the presence of Cs-137, but also by the total sum of the chemicals getting into the coastal area of Lake Drūkšiai from the Ignalina NPP industrial site. Synergetic toxic effects may be caused by the exposure to the whole variety of toxicants. 


\section{REFERENCES}

1. Д. Марчюлёнене, Р. Душаускене-Дуж, Э. Мотеюнене, Р. Швобене, Радиохемоэкологчческая ситуация в оз. Друкшяй - водоёме-охладителе Игналиской АЭС, Вильнюс, Литва: Academia, 1992. (D. Marčiulionienè, R. Dušauskienè-Duž, E. Motiejūnienè, R. Švobienè, Radio-chemicalecological situation of Lake Drukshiai, the coolingpond of the Ignalina NPP, Vilnius, Lithuania: Academia, 1992.)

2. А. В. Трапезников, И. В. Молчанова, Е. Н. Караваева, В. Н. Трапезникова, Миграция радионуклидов в пресноводных и наземных экосистемах, т. 1, Екатеринбург, Россия: УРАЛ. YH-TA, 2007. (A. V. Trapeznikov, I. V. Molchanova, E. N. Karavaeva, V. N. Trapeznikova, Radionuclide Migration in Freshwater and Terrestrial Ecosystems, vol. 1, Yekaterinburg, Russia: University of Ural, 2007.)

3. D. Chicea, M. Raciuciu, "On the effects of low doses (o-1,2 Gy) beta radiation on Zea mays seeds on 12 days plantlets," Rom. Journ. Phys., vol. 52, no. 5-7, pp. 633-640, 2007.

Retrieved from:

http://www.nipne.ro/rjp/2007 52 5-

6/0633_0641.pdf

Retrieved on: Dec. 9, 2016

4. О. В. Орлова, В. С. Сухов, В. А. Воденеев, “Анализ возможности использования разности электрических потенциалов для оценки влияния повышенного радиационного фона на солеустойчивость проростков пшеницы," Вестник Нижегородского университета им. Н. И. Лобачевского, но. 5, стр. 118 - 122, 2009. (O. V. Orlova, V. S. Suhov, V. A. Vodeneev, "The Analysis of Possibility to use the Difference of Electric Potential for Evaluation of Impact and Increased Radiation to salt tolerance of wheat seedlings," J. Lobachevsky Univ. N. Novgorod, no. 5 , pp. $118-122,2009$.)

Retrieved from:

https://cyberleninka.ru/article/v/analiz-

vozmozhnosti-ispolzovaniya-raznosti-elektricheskihpotentsialov-dlya-otsenki-vliyaniya-povyshennogo-

radiatsionnogo-fona-na

Retrieved on: Dec. 9, 2016

5. S. A. Geras'kin, A. A. Oudalova, J. K. Kim, V. G. Dikarev, N. S. Dikareva, "Cytogenetic effect of low dose gamma-radiation in Hordeum vulgare seedlings: non-linear dose-effect relationship," Radiat. env. biophys., vol. 46, no. 1, pp. $31-41$, Mar. 2007.

DOI: $10.1007 /$ s00411-006-0082-Z

PMid: 17171549

6. S. Geras'kin, T. Evseeva, A. Oudalova, "Effects of long-term chronic exposure to radionuclides in plant populations," J. Environ. Radioact., vol. 121, pp. 22 - 32, Jul. 2013.

DOI: 10.1016/j.jenvrad.2012.03.007

PMid: 22483340

7. D. K. Gupta, F. Tawussi, L. Hamann, C. Walther, "Moderate Uranium Disturbs the Nutritional Status and Induces Oxidative Stress in Pisum sativum L.," J. Plant Physiol. Pathol., vol. 4, no. 1, Mar. 2016.

DOI: 10.4172/2329-955X.1000142

8. П. Ю. Волкова, С.А. Гераськин, “Анализ полиморфизма супероксиддисмутазы в хронически облучаемых популяциях сосны обыкновенной," Радиационная биология. Радиоэкология, т. 52, но. 4, стр. 370 - 380, 2012. (P. Yu. Volkova, S. A. Geras'kin, "The Analysis of Superoxide Dismutase's Polymorphism in Chronically Exposed Populations of Pinus sylvestris," Radiational Biology. Radioecology, vol. 52, no. 4, pp. $370-380,2012$.)

Retrieved from:

http://libryansk.ru/files/projectimage/eco/text/volk ova analiz.pdf

Retrieved on: Dec. 9, 2016

9. T. Evseeva, T. Majstrenko, S. Geras'kin, J. E. Brown E. Belykh, "Estimation of ionizing radiation impact on natural Vicia cracca populations inhabiting areas contaminated with uranium mill tailings and radium production wastes," Science of the Total Environment, vol. 407, no. 20, pp. 5335 - 5343 , Oct. 2009.

DOI: 10.1016/j.scitotenv.2009.06.037 PMid: 19640568

10. K. Jokšas, A. Galkus, R. Stakẻnienè, "Drūkšiu ežero dugno nuosèdu medžiaginè sudètis ir poliutanty kaupimasi ypatumai," in Ignalinos $A E$ poveikis gamtai ir visuomenei, Vilnius, Lietuva: Geologijos ir geografijos institutas, 1995, psl. 36 - 44. (K. Jokšas, A. Galkus, R. Stakènienè, "The Composition's Texture of Bottom Sediment in Lake Drūkšiai and the Feature of Pollutant's Accumulation," in The Impact of the Ignalina NPP on the Environment and Society, Vilnius, Lithuania: Institute of Geography and Geology, 1995, pp. 36 - 44.)

11. A. Galkus, "Drūkšių ežeras kaip sedimentologenetinè erdvè," Geografija, tom. 33, psl. 45 - 52, 1997 (A. Galkus, "Lake Drūkšiai as space for sedimentgenesis," Geografija, vol. 33, pp. $45-52,1997$.)

12. J. Mažeika, Radionuclides in Geoenvironment of Lithuania, Vilnius, Lithuania: Institute of Geology, 2002.

13. A. Gudelis, V. Remeikis, A. Plukis, D. Lukauskas, "Efficiency calibration of HPGe detectors for measuring environmental samples," Environ. Chem. Phys., vol. 22, no. 3-4, pp. 117 - 125, 2000.

14. И.Г. Магоне, "Биоиндикация фитотоксичности выбросов автотранспорта,” в Воздействие выбросов автотранспорта на природную среду, О. Л. Качалова, ред., Рига, СССР: Зинатние, 1989, стр. 108 - 116. (I. G. Magone, "Bioindication of toxicity of transport emission," in Bioindication of toxicity of transport emissions in the impact of highway emissions on natural environment, O. L. Kachalova, Ed., Riga, USSR: Zinatne, 1989, pp. 108116.)

15. Wang W. "Use of Plants for the Assessment of Environmental Contaminants," Reviews of Environmental Contamination and Toxicology, vol. 126, pp. 88 - 127, 1992.

DOI: $10.1007 / 978-1-4613-9748-9 \_2$

16. Г. Г. Поликарпов, Радиоэкология морских организмов, Москва, Россия: Атомиздат, 1964. (G. G. Polikarpov, The Radioecology of marine organisms, Moscow, Russia, 1964.)

17. D. Marčiulionienė, J. Mažeika, R. Paškauskas,

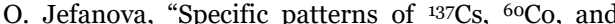
$54 \mathrm{Mn}$ accumulation by macrophytes and bottom sediments," Zoology and ecology, vol. 24, no. 2, pp. 168 - 177, Jul. 2014.

Retrieved from:

https://www.researchgate.net/publication/2637031 2111 Specific patterns of $137 \mathrm{Cs} 60 \mathrm{Co}$ and 54 Mn accumulation by macrophytes and bottom $s$ ediments

Retrieved from: Dec. 12, 2016

18. H. Marschner, Mineral nutrition of higher plants, 2nd ed., London, UK: Academic, 1995.

19. D. Marčiulionienė, B. Lukšienè et al., "Radiocesium Phytotoxicity to Single Cell and Higher Plants," in Impact of Cesium on Plants and the Environment, D. Gupta, C. Walther, Eds., Cham, Switzerland: Springer IP, 2017, ch. 12, pp. $209-230$. 
DOI: $10.1007 / 978-3-319-41525-3$

20. D. Marčiulionienè, B. Lukšienė, D. Montvydienè, G. Maksimov, J. Darginavičienè, V. Gavelienè, "Influence of ${ }^{137} \mathrm{Cs}$ and ${ }^{90} \mathrm{Sr}$ on vegetative and generative organs of Lepidium sativum and Tradescantia clone 02," Nukleonika, vol. 51, no. 4, pp. 193 - 201, Nov. 2006.
Retrieved from:

http://www.nukleonika.pl/www/back/full/vol51 20 o6/v51n4p193f.pdf

Retrieved on: Dec. 16, 2016 